\title{
Alternative Splicing Unmasks Dendritic and Axonal Targeting Signals in Metabotropic Glutamate Receptor 1
}

\author{
Anna Francesconi ${ }^{1}$ and Robert M. Duvoisin ${ }^{1,2}$ \\ Departments of ${ }^{1}$ Ophthalmology and ${ }^{2}$ Cell Biology, Weill Medical College of Cornell University, New York, New York 10021
}

Precise targeting of neurotransmitter receptors to different neuronal compartments is a fundamental step for the establishment and function of synaptic circuitry. Group I metabotropic glutamate receptors, mGluR1 and mGluR5, control glutamatergic neurotransmission by acting both postsynaptically and presynaptically. Four alternatively spliced variants of the mGluR1 gene exist, which differ in their signaling properties and subcelIular localization. The present study was undertaken to identify the molecular signals responsible for trafficking of these receptors to different neuronal compartments. Here we report that targeting of mGluR1 to dendrites and axons of transfected retina neurons is controlled by alternative splicing. We have identified in the tail of the receptor a tripeptide motif, which is necessary and sufficient to exclude the splice variant mGluR1b from distal dendrites and to drive it to the axon. This motif, which is present in all the mGluR1 receptors, is masked in mGluR1a by a dominant dendritic signal sequence harbored by the extended C-terminal tail of this splice variant. Furthermore, we show that the identified axonal and dendritic targeting signals are also necessary and sufficient to localize mGluR1b and mGluR1a to the apical and basolateral compartment of Madin-Darby canine kidney cells, respectively, consistent with the existence of common trafficking components for polarized targeting in epithelial cells and neurons.

Key words: mGluR1; alternative splicing; vectorial trafficking; axonal and dendritic targeting; apical and basolateral targeting; retina neurons; MDCK cells
Targeting of neurotransmitter receptors to postsynaptic and presynaptic sites requires their correct sorting, insertion and retention at the plasma membrane, and clustering. While the mechanisms regulating exocytotic and endocytotic trafficking and synaptic clustering of complex membrane receptors have begun to be clarified, the molecular signals driving targeting to dendrites and axons remain for the most part unknown (Winckler and Mellman, 1999b). Because neurons derive from the primitive neuroepithelium, they may share mechanisms for vectorial trafficking with epithelial cells, where junctional complexes separate the plasma membrane into basolateral and apical surfaces. Indeed, it is believed that these two domains may correspond to the somatodendritic and axonal compartments, respectively (RodriguezBoulan and Powell, 1992). Basolateral sorting signals are usually formed by short cytosolic motifs, often dominant over apical determinants (Matter and Mellman, 1994). For some proteins, basolateral signals also determine dendritic targeting (West et al., 1997a; Jareb and Banker, 1998). In contrast, apical signals can be formed by carbohydrate, lipid, and proteinaceous moieties present in the luminal, transmembrane, or cytosolic region (RodriguezBoulan and Gonzalez, 1999). It is believed that such moieties may

Received Oct. 16, 2001; revised Dec. 17, 2001; accepted Dec. 27, 2001.

This work was supported by National Institutes of Health Grant EY09534, Research to Prevent Blindness, and the Ziegler Foundation. A.F. is a National Alliance for Research on Schizophrenia and Depression Young Investigator. We thank Drs. R. Kuhn, T. Mikawa, K. Mostov, J.-P. Pin, E. Rodriguez-Boulan, and C. Romano for the generous gift of reagents; Drs. A. Musch and L. Leung for technical advice; G. Bottaro and A. Edmondson for skilled technical assistance; G. Wu for generating the mGluR1a-myc construct; and Drs. B. Bettler, M. Jacob, G. Kreitzer, C. Romano, J. Wagner, and M. Wiedmann for critical appraisal of this manuscript.

Correspondence should be addressed to Dr. Anna Francesconi, Department of Neuroscience, Albert Einstein College of Medicine, 1300 Morris Park Avenue, Bronx, NY 10461. E-mail: afrances@aecom.yu.edu.

Dr. Duvoisin's present address: Neurological Sciences Institute, Oregon Health and Science University, Beaverton, OR 97006.

Copyright (C) 2002 Society for Neuroscience $\quad 0270-6474 / 02 / 222196-10 \$ 15.00 / 0$ promote association with sphingolipid-cholesterol rafts, which would then mediate apical transport (Simons and Ikonen, 1997). However, the existence of rafts in vivo and their role in trafficking are still controversial (Weimbs et al., 1997; Jareb and Banker, 1998; Ledesma et al., 1998; Jacobson and Dietrich, 1999). Axonal trafficking is still poorly understood, and although sequence segments that permit proteins to enter the axon have been described previously (West et al., 1997b; Stowell and Craig, 1999), no discrete targeting signal has yet been reported.

Group I metabotropic glutamate receptors (mGluRs) induce slowly arising excitation in postsynaptic neurons through phosphoinositide hydrolysis and calcium release. Furthermore, they have also been shown to control glutamate release presynaptically (Herrero et al., 1992; Rodriguez-Moreno et al., 1998), but the molecular identity of the receptor involved in this function remains uncertain. mGluR1 takes part in the regulation of synaptic plasticity in the cerebellum and hippocampus (Aiba et al., 1994a,b; Conquet et al., 1994). At least four alternatively spliced variants of mGluR1 exist, which diverge in their cytoplasmic C-terminal tails (Conn and Pin, 1997). These receptors differ in signaling properties in heterologous cells (Pin and Duvoisin, 1995) and in their subcellular localization in neurons (Ferraguti et al., 1998). However, their specific contribution to mGluR1 function in the brain is not known.

We have examined whether differences in the tails of the splice variants mGluR1a (Houamed et al., 1991; Masu et al., 1991) and mGluR1b (Tanabe et al., 1992) may affect receptor trafficking. Our findings show that these receptors localize to different compartments when expressed in retina neurons and epithelial cells. MGluR1a is somatodendritic in neurons and basolaterally targeted in Madin-Darby canine kidney (MDCK) cells, whereas mGluR1b is present in the axon and apically targeted. We have identified in the cytoplasmic tail of mGluR1 a tripeptide, which 
constitutes a novel signal for vectorial trafficking functioning both in axonal and apical targeting. This motif is masked in mGluR1a by a dominant dendritic and basolateral signal harbored by the C-terminal tail of this receptor.

\section{MATERIALS AND METHODS}

Recombinant constructs. Recombinant rat mGluRs were cloned in the expression vectors pRc-CMV, pCDNA3.0, and pUHD10.3 (Gossen and Bujard, 1992) by standard techniques. PCR-mediated site-directed mutagenesis (Expand High Fidelity; Roche Molecular Biochemicals, Indianapolis, IN) was used to insert the EQKLISEEDL epitope in frame after $\mathrm{Ala}^{30}$ in the mGluR1 ectodomain and to introduce point mutations and deletions in the mGluR1b tail. Serial deletions of the mGluR1a $\mathrm{C}$-terminal tail were generated by introducing stop codons after amino acids Val ${ }^{1182}$, Pro ${ }^{1148}$, Phe ${ }^{1111}$, Ser ${ }^{1071}$, and Lys ${ }^{1011}$ using the QuikChange XL site-directed mutagenesis kit (Stratagene, La Jolla, CA). For the vesicular stomatitis virus glycoprotein G (VSV-G)-mGluR chimeras, the $t 5045 \mathrm{VSV}-\mathrm{G}$ gene was used; this permitted accumulation of the chimeric proteins in the endoplasmic reticulum at $39^{\circ} \mathrm{C}$ and their release by switching to $32^{\circ} \mathrm{C}$. The constructs were generated by PCR and cloned by standard techniques. VSVG ${ }^{\text {ts }}$-stop was created by introducing a stop codon after Arg ${ }^{483}$ of VSV-G; the VSVG ${ }^{\text {ts }}-1$ atail, VSVG ${ }^{\text {ts }}-1$ btail, and VSVG ${ }^{\text {ts }}-1 \mathrm{~b} \Delta^{877-880}$ chimeras were generated by joining in-frame VSV-G (from residues 1-482) to the tail of mGluR1a, mGluR1b, or mGluR1b $\Delta^{877-880}$ (starting at residue 841 ). All constructs were verified by sequencing.

Expression in MDCK cells. To generate stable clones, the parental T23 cells expressing the tetracycline-repressible transactivator (a gift from K. Mostov, Stanford University, Stanford, CA) were cotransfected with the pUHD10.3 constructs and the pCB7 vector using LipofectAMINE Plus (Invitrogen, Gaithersburg, MD) and selected for hygromycin resistance $(200 \mu \mathrm{g} / \mathrm{ml})$. Cells were maintained at $5 \% \mathrm{CO}_{2}$ in DMEM supplemented with $10 \%$ fetal bovine serum, nonessential amino acids, and kanamycin with or without $20 \mathrm{ng} / \mathrm{ml}$ doxycycline. To obtain polarized monolayers, cells were plated at confluency on Transwells (Costar, Cambridge, MA) polycarbonate filters $\left(2.5 \times 10^{5}\right.$ and $10^{5}$ cells for 12 - and $6.5-\mathrm{mm}-$ diameter filters, respectively) and grown for $48 \mathrm{hr}$ with doxycycline. After an extensive wash, the cells were incubated for 48-72 hr without doxycycline. For clones expressing the VSV-G constructs, cells plated at confluency on filters were grown for $48 \mathrm{hr}$ with and then for $48 \mathrm{hr}$ without doxycycline at $37^{\circ} \mathrm{C}$. After adding $5 \mathrm{~mm}$ butyric acid to the media, the cells were incubated at $39^{\circ} \mathrm{C}$ overnight and at $32^{\circ} \mathrm{C}$ for different time points. Recombinant constructs were also transiently expressed in polarized MDCK cells plated at confluency on $12 \mathrm{~mm}$ glass coverslips and grown for 2-3 d. In these experiments, replication-defective adenovirus covalently coated with poly-L-lysine (Allgood et al., 1997) was incubated for $30 \mathrm{~min}$ at room temperature with 100-200 ng of plasmid DNA and then for 30 min with poly-L-lysine at a molar concentration 125 times in excess of the plasmid DNA. The adenovirus-DNA complex, at a multiplicity of infection of 1500:1, was added to the cells and incubated for 4 $\mathrm{hr}$ at $37^{\circ} \mathrm{C}$; fresh media were then added, and the cells were returned to $37^{\circ} \mathrm{C}$ for $24-48 \mathrm{hr}$.

Retina cultures. Retinas were dissected from White Leghorn E10 chick embryos in calcium- and magnesium-free buffer (in mM: $131 \mathrm{NaCl}, 41$ $\mathrm{KCl}, 9.2 \mathrm{Na}_{2} \mathrm{HPO}_{4}, 4.5 \mathrm{KH}_{2} \mathrm{PO}_{4}, 9.4 \mathrm{NaHCO}_{3}, 122$ D-glucose), dissociated with $0.2 \%$ trypsin, and triturated. Cells were plated on poly-Llysine-coated glass coverslips at $5 \times 10^{5} / \mathrm{cm}^{2}$ density and incubated with basal medium Eagle's (BME), 3\% fetal bovine serum, and antibiotics at $37^{\circ} \mathrm{C}$ in $5 \% \mathrm{CO}_{2}$. In some experiments, $5 \mu \mathrm{M}$ arabinoside $\mathrm{C}$ was added to contain non-neuronal cell proliferation. Transfection was performed by calcium phosphate precipitation and glycerol shock at embryonic day equivalent (EE) 12 . The transfected neurons were then incubated at $37^{\circ} \mathrm{C}$ and fixed at EE 14-15 with $4 \%$ formaldehyde and $4 \%$ sucrose at room temperature. Neurons transfected with the VSV-G chimeras were incubated with $5 \mathrm{~mm}$ butyric acid at $39^{\circ} \mathrm{C}$ for $16 \mathrm{hr}$ and at $32^{\circ} \mathrm{C}$ for $6 \mathrm{hr}$ before fixation.

Antibodies. The following antibodies were used at the specified concentrations: rabbit anti-c-myc IgG (Santa Cruz Biotechnologies, Santa Cruz, CA) at $0.6 \mu \mathrm{g} / \mathrm{ml}$ for immunofluorescence (IF) and $0.2 \mu \mathrm{g} / \mathrm{ml}$ for Western blot (WB); mGluR1 $\alpha /$ mGluR5 rabbit antiserum (m5-17b; a gift from C. Romano, Washington University, St. Louis, MO) at 1:100 for IF and 1:1000 for WB; mGluR1b rabbit antiserum (a gift from R. Kuhn, Novartis) at 1:200 for IF and 1:500 for WB; calnexin rabbit antiserum at 1:2000 (StressGen, Victoria, British Columbia, Canada); and mouse anti-caveolin-1 IgG at 1:5000 (Transduction Laboratories, Lexington, KY). Monoclonal antibodies anti-GP114 and anti-VSV-G ectodomain (clone $5 \mathrm{~F} \alpha \mathrm{G}$; gifts from E. Rodriguez-Boulan, Weill Medical College) were diluted at 1:50; anti-MAP2 (AP20; Roche) was diluted at $5 \mu \mathrm{g} / \mathrm{ml}$; and anti-neurofilament heavy subunit (NE14; Sigma, St. Louis, MO) was diluted at 1:200. Anti-E-cadherin (rr1; developed by B. Gumbiner, Sloan Kettering Institute, New York, NY) used at 1:50 was obtained from the Developmental Studies Hybridoma Bank (Iowa City, IA). Cy2conjugated goat anti-rabbit and anti-mouse $\operatorname{IgG}$ were used at 1:500, respectively, and $\mathrm{Cy} 3$-conjugated goat anti-rabbit and anti-mouse IgG were used at 1:1600 and 1:600, respectively (Jackson ImmunoResearch, West Grove, PA).

Immunofluorescence. Cells plated on glass coverslips or filters were fixed with $4 \%$ paraformaldehyde in PBS (containing in mM: $1 \mathrm{MgCl}_{2}$ and $0.1 \mathrm{CaCl}_{2}$ for polarized cells), permeabilized with $0.3 \%$ Triton $\mathrm{X}-100$ in PBS for $10 \mathrm{~min}$ at room temperature, and incubated with blocking solution (10\% normal goat serum and $2 \%$ bovine serum albumin) for 1 $\mathrm{hr}$ at room temperature. Primary antibodies diluted in blocking solution were applied for $18 \mathrm{hr}$ at $4^{\circ} \mathrm{C}$, washed out with PBS, and reacted with $\mathrm{Cy} 2-$ and $\mathrm{Cy} 3$-conjugated IgGs diluted in blocking solution for $1 \mathrm{hr}$ at room temperature. For nuclear staining, after immunolabeling the cells were washed with PBS, incubated with $2.5 \mu \mathrm{g} / \mathrm{ml}$ RNase at $37^{\circ} \mathrm{C}$ for 30 min, washed with PBS, and incubated with $1 \mu \mathrm{g} / \mathrm{ml}$ propidium iodide at room temperature for $20 \mathrm{~min}$. After washing again with PBS, the cells were mounted on glass slides. Images were captured with a CCD camera (Sensys; Roper Scientific, Trenton, NJ) mounted on a Zeiss (Thornwood, NY) Axiovert 35 microscope using IPLab software (Scanalytics, Fairfax, VA). Confocal images were acquired with a Zeiss LSM510 microscope and converted for presentation and quantification of fluorescence intensity with MetaMorph (Universal Imaging, Downingtown, PA). Statistical analysis was performed with Instat 2.00 (GraphPad Software).

In vivo labeling of retina neurons. Live transfected neurons were incubated at $37^{\circ} \mathrm{C}$ for $30 \mathrm{~min}$ with c-myc antibody diluted in warm BME. Cells were washed with warm PBS containing (in $\mathrm{mM}$ ): $1 \mathrm{MgCl}_{2}$ and 0.1 $\mathrm{CaCl}_{2}$, fixed with $4 \%$ paraformaldehyde for $5 \mathrm{~min}$ at room temperature, washed with PBS, and incubated with Cy3-conjugated IgG for $1 \mathrm{hr}$ at room temperature.

Other methods. Inositol accumulation experiments were performed as described previously (Francesconi and Duvoisin, 1998). For domainselective surface labeling of receptors, $2 \times 10^{6}$ cells were plated on 24 $\mathrm{mm}$ polycarbonate filters and grown for $3 \mathrm{~d}$ with and $3 \mathrm{~d}$ without doxycycline; the cells were then placed on ice and washed with cold HBSS with calcium and magnesium containing $0.2 \%$ albumin. To label apical and basolateral surface receptors, rabbit anti-myc IgG was diluted at $2 \mu \mathrm{g} / \mathrm{ml}$ in HBSS and albumin and added to the top or bottom chamber of Transwells ( 0.5 and $1.5 \mathrm{ml}$, respectively); HBSS and albumin were added to the chamber not receiving the antibody. After $1 \mathrm{hr}$ of incubation on ice at $4^{\circ} \mathrm{C}$, the cells were washed three times with cold HBSS and albumin; the filters were then excised from the collars, and the cells were scraped, pelleted, and resuspended in $1 \mathrm{ml}$ of lysis buffer $(20 \mathrm{mM}$ HEPES, $0.1 \mathrm{~mm}$ EGTA, $100 \mu \mathrm{M} \mathrm{MgSO}, 150 \mathrm{~mm} \mathrm{NaCl}, 0.2 \%$ Nonidet P-40, $1 \%$ Triton $\mathrm{X}-100$, and $2 \% \beta$-octylglucoside, $\mathrm{pH} 8.0$ ) with protease inhibitors. After $1 \mathrm{hr}$ of incubation on ice, the lysate was centrifuged at 12,000 rpm to remove insoluble material and incubated with $100 \mu \mathrm{l}$ of protein A-Sepharose (Amersham Biosciences, Piscataway, NJ) for $4 \mathrm{hr}$ at room temperature. Bound proteins were washed three times with PBS and eluted with sample buffer containing $100 \mathrm{~mm}$ DTT. Western blotting and signal detection have been described previously (Francesconi and Duvoisin, 1998). To assess protein solubility in Triton X-100, MDCK cells were plated at confluency in six-well clusters, grown for $3 \mathrm{~d}$ with and $3 \mathrm{~d}$ without doxycycline, and lysed. Solubilization in 2\% Triton X-100 and flotation gradients were performed essentially as described previously (Harder et al., 1998); proteins were extracted from the gradient fractions and separated by 7 and 15\% SDS-PAGE for Western blot analysis.

\section{RESULTS}

\section{Differential targeting of mGluR1 splice variants in neurons and MDCK cells}

The a and b splice variants of mGluR1 diverge at residue 886 in the C-terminal tail, after which 313 residues are inserted in mGluR1a, and 20 residues are inserted in mGluR1b (see Fig. $4 A$ ). The two receptors differ in their functional properties in that mGluR1a but not mGluR1b shows constitutive activity as 
A
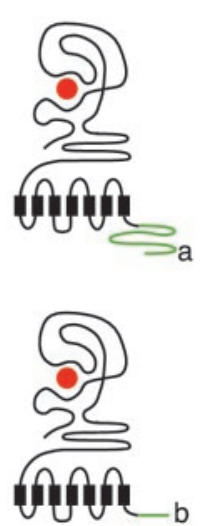

Figure 1. Differential targeting of mGluR1a-myc and mGluR1b-myc in neurons. $A$, Schematic representation of mGluR1a and mGluR1b; the nonconserved distal portion of the intracellular $\mathrm{C}$-terminal tail is highlighted in green. Retina neurons expressing myc-tagged mGluR1a $(B)$ and mGluR1b $(D, E)$ and double labeled for MAP2 or NF-H are shown. Background signal from fibroblast-like cells onto which neurons adhere in this coculture system is visible in some images. MAP2 and NF-H label the somatodendritic and axonal compartments, respectively, of some but not all retinal neurons. Note the exclusion of mGluR1b from MAP2positive dendrites ( $D$; single optical section). Arrowheads point to receptor-labeled processes. MGluR1a $(C)$ and mGluR1b $(F)$ are present on the plasma membrane, as shown by in vivo labeling of surface receptors (arrow in $F$ points to the cell body of the labeled neuron). Scale bars, $20 \mu \mathrm{m}$.
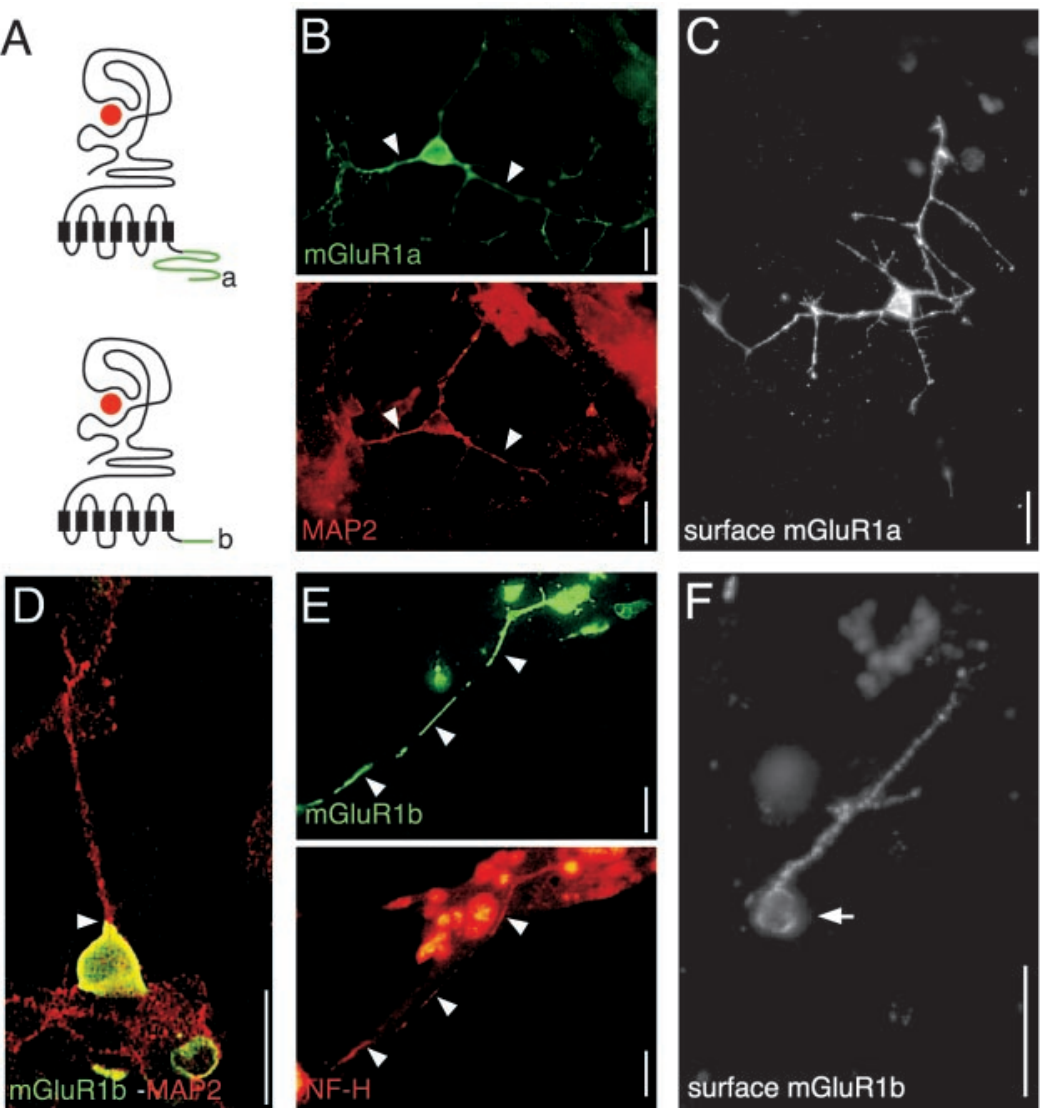

well as higher potency in response to agonist stimulation, suggesting that they may subserve different signaling functions. We questioned whether the structural differences present in the cytoplasmic tails might influence mGluR1 targeting in neurons. To this end, we introduced a myc epitope in the ectodomain of the receptor after the leader peptide (at $\mathrm{Ala}^{30}$ ) and transfected these myc-tagged mGluRs in chick retina neurons in culture. Dendrites were identified by labeling with an anti-MAP2 antibody, and axons were identified by labeling with anti-neurofilamentphosphorylated heavy subunit (NF-H; Shaw et al., 1986). Because not all retina cells express these markers, targeting to or exclusion from dendrites of myc-tagged mGluRs was defined by double labeling transfected cultures and scoring only MAP2- and mycpositive transfected neurons. Likewise, axonal targeting was defined by double labeling and scoring NF-H- and myc-positive processes. Using these criteria, we found that mGluR1a-myc colocalized with MAP2 in $100 \%$ of scored cells (Fig. $1 B ; n=28$, eight independent experiments). In two cells from the eight experiments analyzed, the receptor was found in both axon and presumptive dendrites. Labeling of live transfected neurons with the myc antibody confirmed that mGluR1a-myc was correctly transported to the plasma membrane (Fig. 1C). Parallel analyses of mGluR1b-myc-transfected cultures showed that this receptor differed strikingly from mGluR1a in its localization in neurons. MGluR1b-myc was excluded from the distal regions of MAP2labeled processes in $100 \%$ of cells (Fig. $1 D ; n=18$, six independent experiments) and localized primarily to the soma and the dendrite proximal segment. Furthermore, mGluR1b-myc was present in soma and axons in $100 \%$ of scored cells (Fig. $1 E ; n=$ 22 , nine independent experiments). The presence of the receptor on the plasma membrane was also confirmed by in vivo labeling of transfected neurons (Fig. $1 F$ ).
We then tested whether the structural information determining dendritic and axonal targeting of mGluR1a-myc and mGluR1bmyc was recognized in polarized epithelial cells and used for their delivery to distinct compartments. For this purpose, we generated stable MDCK clones expressing myc-tagged mGluRs under the repressible tetracycline promoter (Gossen and Bujard, 1992). The two splice variants of mGluR1 were expressed at comparable levels, properly folded, and delivered to the plasma membrane as demonstrated by Western blot, biotinylation of surface proteins (data not shown), and functional assay of receptor responses to agonist stimulation (Fig. $2 A, B$ ). The two receptors responded to glutamate stimulation with different potency, consistent with previous reports in other heterologous systems (Flor et al., 1996). In polarized monolayers of cells, mGluR1a-myc selectively localized to the basolateral surface, as shown by colocalization with the cell adhesion protein E-cadherin and absence from the apical compartment labeled with the endogenous protein GP114 (Fig. 2C, left panels). Domain-selective surface labeling also demonstrated the basolateral targeting of the mGluR1a variant (Fig. 2D, left panel). In contrast, mGluR1b was targeted to the apical compartment and absent from the basolateral compartment, as determined by immunofluorescence and domain-selective surface labeling (Fig. 2C,D, right panels).

One proposed mechanisms of apical transport is that proteins targeted to this domain may associate with sphingolipidcholesterol-enriched rafts. Such protein-lipid rafts would then be delivered to the apical compartment. This model is primarily based on the biochemical observation that many but not all apical proteins are insoluble to cold extraction with Triton X-100 and therefore partition to low-density fractions when separated on density step gradients. Using this criteria, we tested whether the two splice variants of mGluR1, in particular the apically targeted 


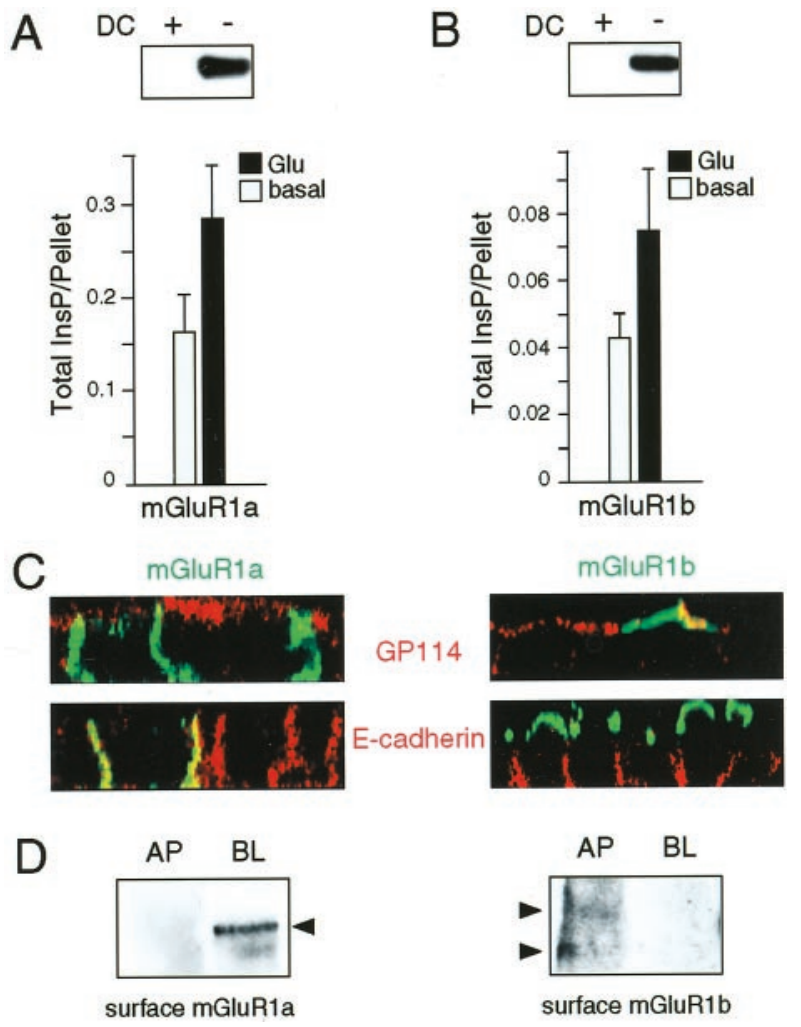

Figure 2. Differential targeting of mGluR1a-myc and mGluR1b-myc in polarized epithelial cells. Expression levels of mGluR1a-myc $(A)$ and mGluR1b-myc $(B)$ in the absence of doxycycline as determined by Western blot analysis are shown. Proper folding and transport to the plasma membrane of the receptors were confirmed by the measurement of glutamate-induced inositol accumulation in stable clones expressing mGluR1a-myc $(A)$ and mGluR1b-myc $(B)$. Results are mean \pm SD of triplicate determinations, representative of two independent experiments. $C, z$-section through confocal images of polarized MDCK cells expressing mGluR1a-myc (left panels, green) and mGluR1b-myc (right panels, green) and double labeled for GP114 and E-cadherin (red). D, Domain selective labeling of surface mGluR1a-myc (left panel) and mGluR1b-myc (right panel). Arrowheads point to the dimeric form of mGluR1a-myc; for mGluR1b-myc, the dimeric form (bottom band) and high molecular weight oligomers (top band) are visible. $A P$, Apical domain; $B L$, basolateral domain; $D C$, doxycycline.

mGluR1b, partitioned together with proteins known to be present in lipid rafts. After solubilization in 2\% Triton X-100 at $4^{\circ} \mathrm{C}$ and separation on Optiprep-sucrose flotation step gradients, both mGluR1a-myc and mGluR1b-myc sedimented in highdensity fractions, as expected for Triton X-100-soluble proteins (Fig. 3). In contrast, caveolin-1, known to be associated with lipid rafts, floated in low-density fractions. These findings argue against raft-mediated transport as the mechanism for mGluR1b apical targeting.

\section{Identification of an axonal and apical targeting signal in mGluR1b}

To define the axonal and apical targeting signal present in mGluR1b, we first generated a truncated myc-tagged receptor (mGluR1-stop) lacking the nonconserved distal region of the tail (Fig. 4A). Surprisingly, the truncated receptor retained targeting properties similar to mGluR1b-myc, both in neurons and polarized epithelial cells. Analysis of mGluR1-stop-transfected neurons double labeled for MAP2 and myc showed that the truncated receptor was also excluded from the distal dendritic processes in

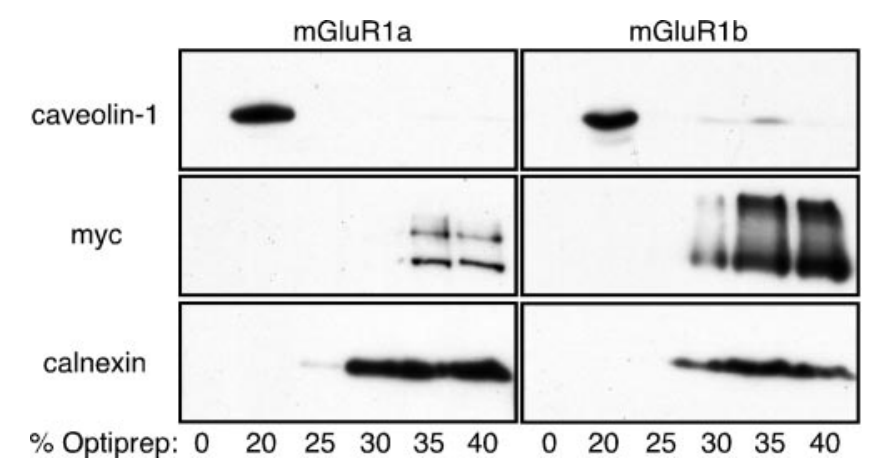

Figure 3. mGluR1a-myc and mGluR1b-myc do not associate with Triton X-100-insoluble lipid rafts. Solubilization of MDCK cells expressing mGluR1a-myc and mGluR1b-myc was performed in 2\% Triton X-100 at $4^{\circ} \mathrm{C}$, and separation of soluble and insoluble protein fractions was performed with an Optiprep-sucrose flotation step gradient. Western blot analysis of extracted proteins shows the presence of both receptors (dimeric forms and oligomers) in the high-density soluble fractions. Caveolin-1 is enriched in the fraction that floats to the interphase of $20 \%$ Optiprep and $10 \%$ sucrose and $0 \%$ Optiprep and $10 \%$ sucrose; calnexin, a transmembrane protein that does not associate with rafts, is found in the high-density fractions. Results shown are representative of two independent experiments.

all the scored cells (Fig. $4 B ; n=6$, three experiments) and present along the axon (Fig. $4 C ; n=7$, four experiments). In vivo labeling of transfected neurons confirmed the presence of the mutant receptor on the plasma membrane (Fig. 4D). In stable MDCK clones expressing mGluR1-stop, the receptor localized in the apical compartment and was absent from the basolateral surface (Fig. 4F). mGluR1-stop was expressed at levels comparable with wild-type mGluRs and folded properly, as indicated by its response to glutamate stimulation (Fig. $4 E$ ). Thus, we concluded that the distal portion of the mGluR1b tail is not required for receptor targeting.

Structure-function studies of the G-protein-coupling domain of mGluR1 have indicated that a short, positively charged region in the conserved proximal portion of the receptor tail could affect its interactions with G-proteins (Mary et al., 1998). We speculated that the reported differences in signaling could instead be explained by the segregation of mGluR1a and mGluR1b to distinct subcellular compartments. To test this, we deleted this region, the RRKK residues at position $877-880$, from myc-tagged mGluR1b (Fig. 5A; mGluR1b $\Delta^{877-880}$ ) and transfected the mutant receptor in retina neurons. By analyzing cells double labeled for MAP2 and myc or NF-H and myc, we found that mGluR1b $\Delta^{877-880}$ was present in both dendrites (Fig. $5 B ; n=8$, three experiments) and axons (Fig. $5 C ; n=12$, four experiments), indicating loss of selective targeting of the mutant receptor. MGluR1b $\Delta^{877-880}$ was efficiently transported to the plasma membrane, as revealed by in vivo labeling of surface receptor in neurons (Fig. $5 D$ ). When expressed in MDCK cells, mGluR1b $\Delta^{877-880}$ showed an expression level comparable with the other receptors (Fig. $5 E$ ); the mutant was present on the plasma membrane, as determined by surface biotinylation (data not shown) and functional assay (Fig. $5 E$ ), indicating that the receptor is properly folded and traffics through the endoplasmic reticulum. In polarized monolayers, mGluR1b $\Delta^{877-880}$ localized to both the basolateral and apical surfaces in a nonpolar manner, as shown by immunofluorescence (Fig. $5 F$ ). Such cellular localization is in agreement with the prediction that signal-less molecules would redistribute to both basolateral and apical compartments. These findings demonstrate 
A

TM7

KPERNVRSAFTTSDVVRMHVGDGKLPCRSNTFLNIFRRKKPGAGNANSNGKSVSWSEPGGRQAPKGQHVWQRLSVHVKTNETA CNQTAVIKPLTKSYQGSGKSLTF SDASTKTLYNVEEEDNTPSAHFSPPSSPSMVVHRRGPPVATTPPLPPHLTAEETPLFLAD SVIPKGLPPPLPQQQPQQPP PQQPPQQPKSLMDQLQGVVTNFGSGI PDFHAVLAGPGTPGNSLRSLYPPPPPPQHLQMLPLHL STFQEESISPPGEDIDDDSERFKLLQEFVYEREGNTEEDELEEEEDLPTASKLTPEDSPALTPPSPFRDSVASGSSVPSSPVS ESVLCTPPNVTYASVILRDYKQSSSTL

mGluR1a

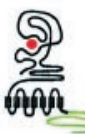

TM7

KPERNVRSAFTTSDVVRMHVGDGKLPCRSNTFLNIFRRKKPGAGNAKKRQPEFSPSSQCPSAHAQL
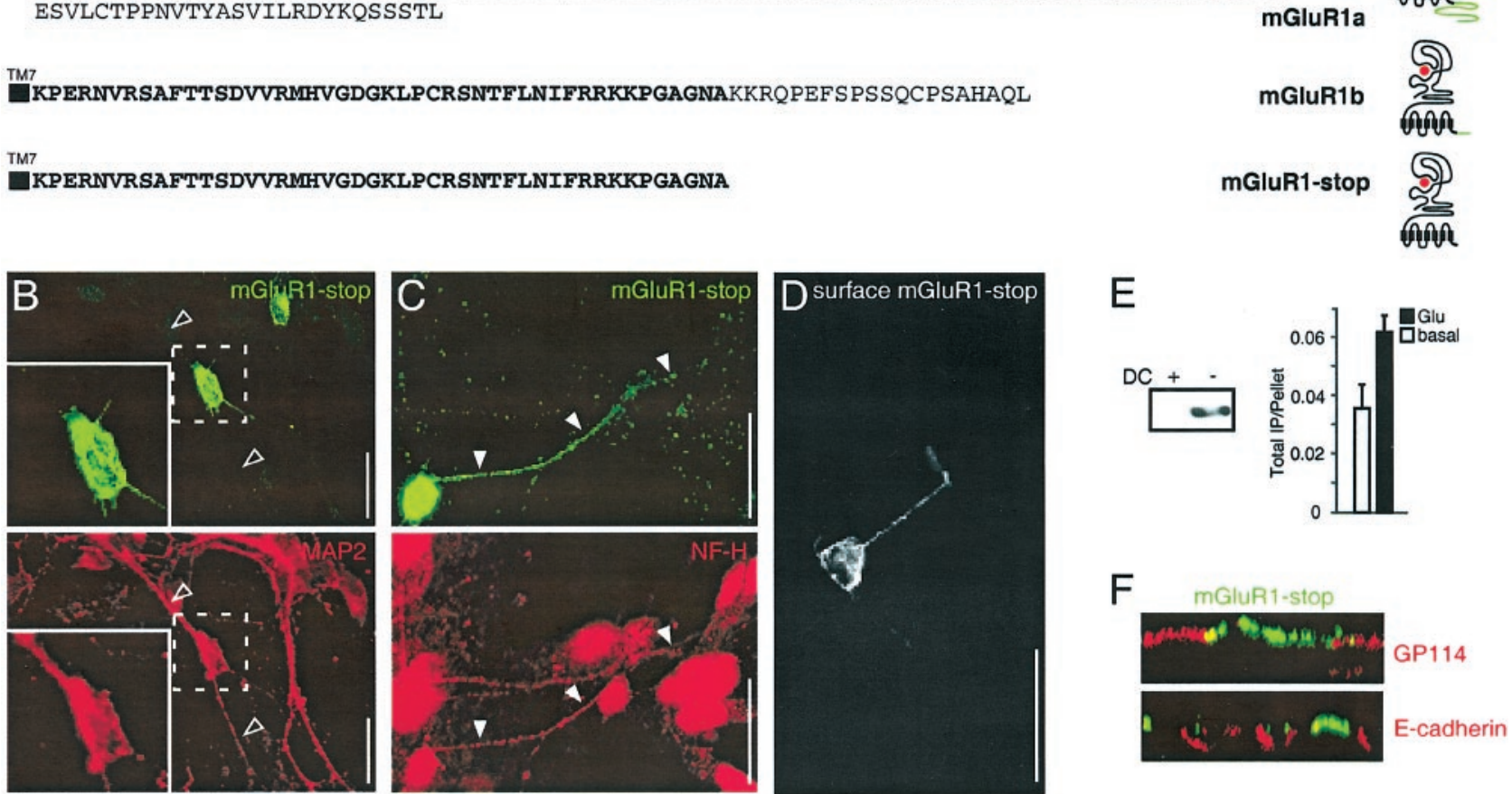

Figure 4. The distal region of the mGluR1b tail does not contribute to receptor targeting. A, Amino acid sequence of the intracellular tails of mGluR1a, mGluR1b, and the truncated mGluR1-stop mutant; the membrane proximal region conserved between mGluR1a and mGluR1b is in bold characters. Retina neurons transfected with mGluR1-stop and double labeled for MAP2 and myc $(B)$ and NF-H and myc $(C)$ are shown. The receptor is excluded from dendrites $(B$, open arrowheads) and present along the axon $(C$, solid arrowheads). $D$, mGluR1-stop is transported to the plasma membrane of neurons as shown by in vivo labeling. Scale bars, $20 \mu \mathrm{m}$. E, Expression level and functional assay of mGluR1-stop activity as described in the legend of Figure $2 A$. F, Localization in polarized MDCK cells; mGluR1-stop ( green) is sorted to the apical domain and absent from the basolateral surface; GP114 and E-cadherin markers for the apical and basolateral domains, respectively, are in red. DC, Doxycycline; TM7, transmembrane domain 7.

that the RRKK ${ }^{877-880}$ peptide comprises the signal determining axonal and apical targeting of mGluR1b.

We used alanine-scanning mutagenesis to determine which of the residues in the $\mathrm{RRKK}{ }^{877-880}$ region of mGluR1b were required for targeting and thus precisely define the axonal and apical signal sequence. Transfection in neurons of myc-tagged receptors carrying the point mutations revealed that single substitution of $\mathrm{Arg}^{877}, \mathrm{Arg}^{878}$, or $\mathrm{Lys}^{879}$ was sufficient to cause redistribution of the mutant receptors to distal neurites (Fig. 6A), whereas substitution of Lys ${ }^{880}$ did not significantly alter the localization of the receptor compared with mGluR1b (Fig. 6A). Consistent with these findings in neurons, individual substitution of $\mathrm{Arg}^{877}$, $\mathrm{Arg}^{878}$, or Lys ${ }^{879}$ generated receptors with a nonpolar distribution in MDCK cells, whereas substitution of Lys ${ }^{880}$ did not, and the receptor localization was confined to the apical domain (Fig. 6B). Thus, the RRK ${ }^{877-879}$ tripeptide constitutes a novel trafficking signal, which is necessary for polarized targeting to the axonal and apical domains of neurons and epithelial cells, respectively.

\section{The RRK ${ }^{877-879}$ motif is masked in mGluR1a by a dominant dendritic and basolateral signal present in the receptor tail}

The $\mathrm{RRK}^{877-879}$ motif is located in a region of the C-terminal tail that is shared by all the splice variants of mGluR1. We speculated that this motif could be masked in mGluR1a by the existence of a dominant dendritic and basolateral signal in the extended tail of the receptor. To map potential trafficking signals, we generated serial deletions of the cytoplasmic tail of myc-tagged mGluR1a (Fig. 7A). When transfected in retina neurons, all the truncated forms of the receptor were delivered to the plasma membrane (Fig. 7C,F,I,L,P). Deletion of the distal 17 amino acids of the mGluR1a-myc tail (mGluR1a-1182stop), did not alter the localization of the receptor in both neurons and epithelial cells (Fig. $7 B, D)$. Larger deletions in the tail region only partially affected the fidelity of receptor targeting. In neurons, mGluR1a-1148stop, mGluR1a-1111stop, and mGluR1a-1071stop primarily localized in dendrites positive for MAP2 labeling (Fig. 7E, $H, K$ ). Consistent with their localization in neurons, these mutant receptors were predominantly targeted to the basolateral domain in epithelial cells (Fig. $7 G, J, M$ ), with only a small percentage of the receptor present in the apical compartment. Finally, deletion of a region spanning between residues 1012 and 1071 (mGluR1a1011stop) caused a drastic change in receptor targeting. In fact, this mutant was present in NF-H-positive processes (Fig. 7O; $n=$ 6) and was mostly excluded from dendrites (Fig. $7 N ; n=6$ ), even if in some cells weak receptor labeling was also detected in more distal regions of the dendritic processes (data not shown; $n=5$ ). Accordingly, in epithelial cells mGluR1a-1011stop was targeted 
A
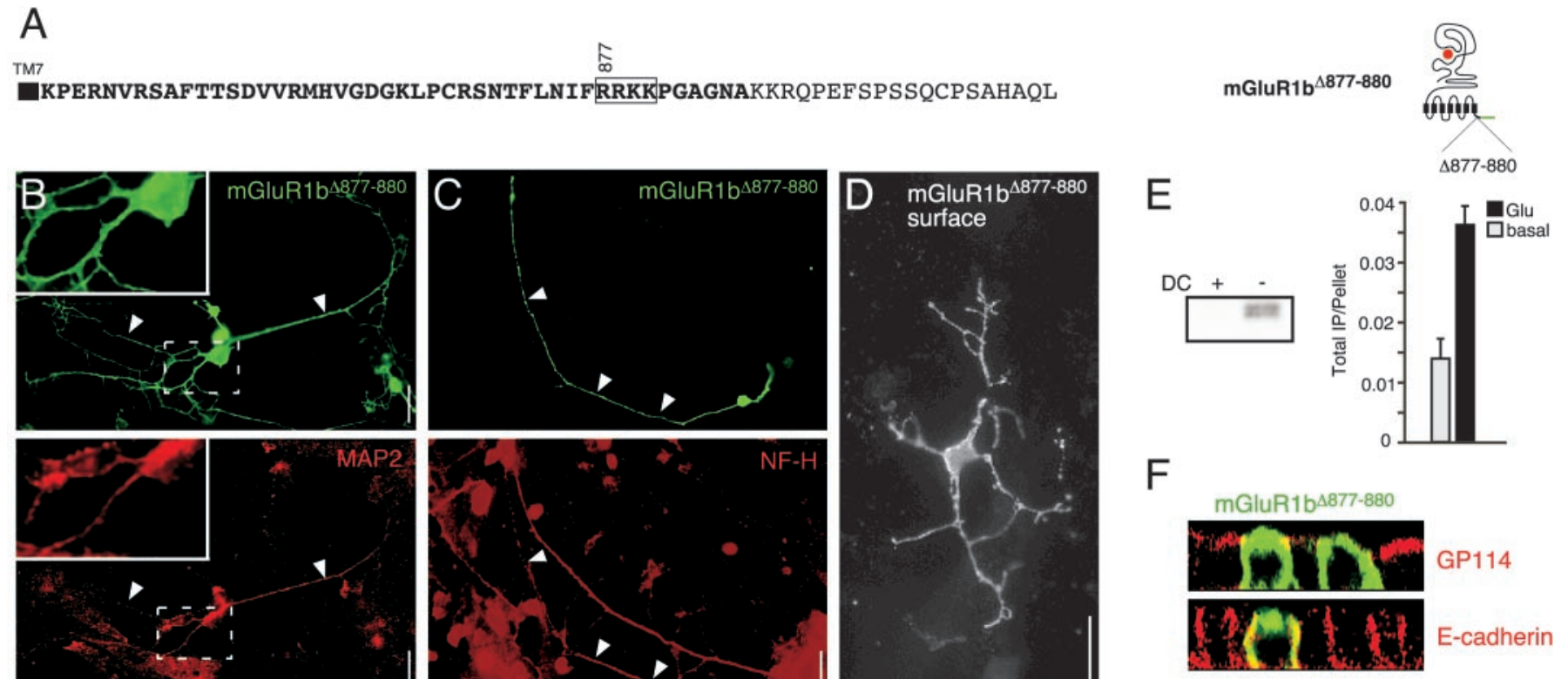
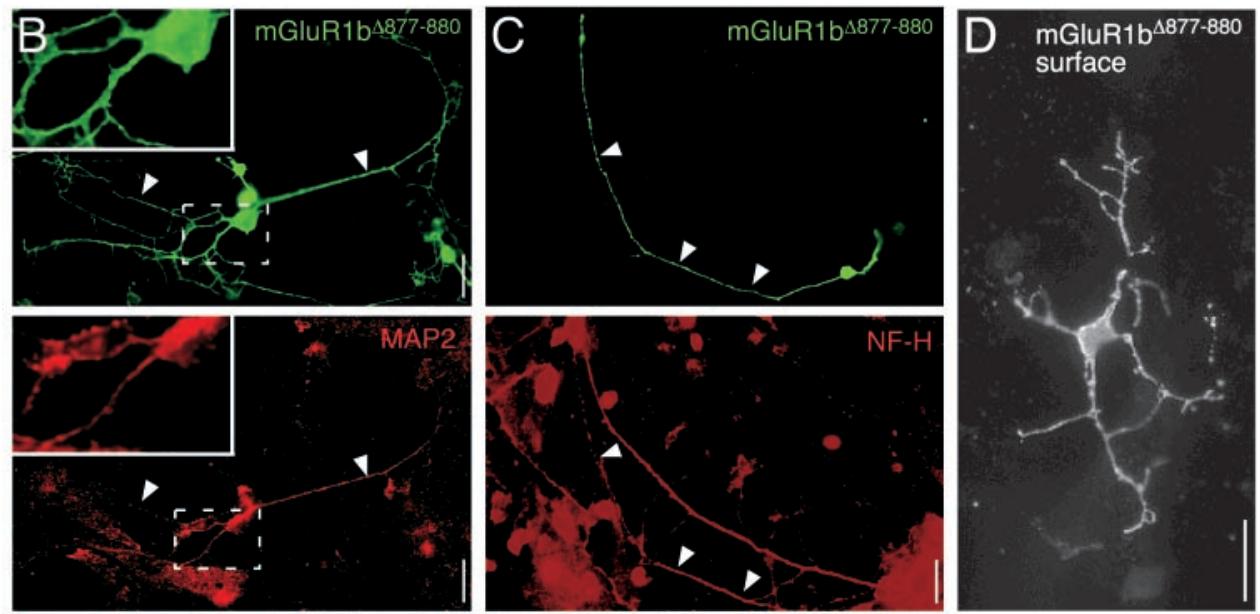

Figure 5. Identification of axonal and apical targeting signals in the mGluR1 tail. $A$, Amino acid sequence of mGluR1b $\Delta^{877-880}$; the deleted amino acids are boxed. Retina neurons were transfected with mGluR1b $\Delta^{877-880}$; the receptor localizes to both dendrites $(B$, arrowheads $)$ and the axon $(C$, arrowheads $)$, as shown by colocalization with MAP2 and NF-H, respectively. $D$, mGluR1b $\Delta^{877-880}$ is efficiently transported to the plasma membrane of transfected neurons. Scale bars, $20 \mu \mathrm{m}$. E, Expression level and activity of mGluR1b $\Delta^{877-880}$ expressed in MDCK cells were determined as described in the legend of Figure $2 A . F$, Localization of mGluR1b $\Delta^{877-880}$ in polarized MDCK cells; the receptor (green) is present in both the apical and basolateral compartments. E-cadherin and GP114 are in red. DC, Doxycycline; TM7, transmembrane domain 7.

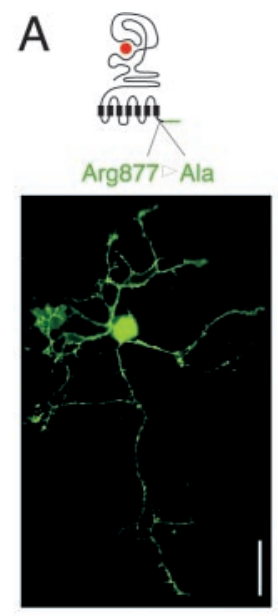

B

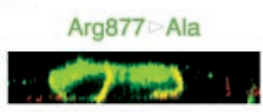

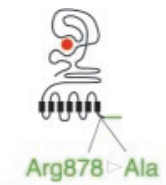

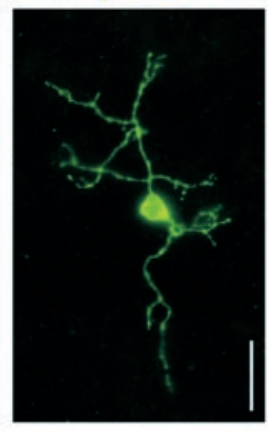

Arg878 Ala

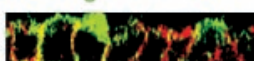

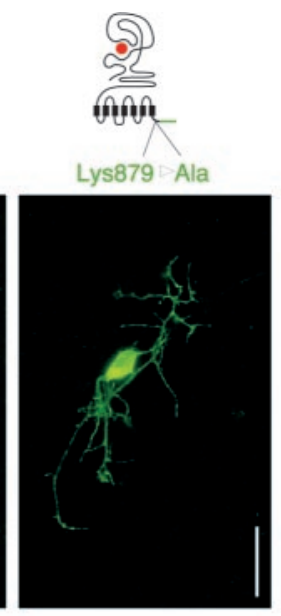

Lys $879>$ Ala

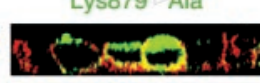

Lys880 Ala

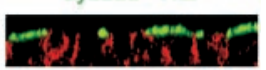

E-cadherin

Figure 6. Alanine-scanning mutagenesis defines the RRK $^{877-879}$ motif as the apical and axonal targeting signal. $A$, Retina neurons transfected with mGluR1b-myc (green) in which $\mathrm{Arg}^{877}, \mathrm{Arg}^{878}$, $\mathrm{Lys}^{879}$, and $\mathrm{Lys}^{880}$ were individually substituted with Ala. Note that the localization of the Arg ${ }^{877}$-, $\mathrm{Arg}^{878}$-, and Lys ${ }^{879}$-Ala mutants resembles that of the mGluR1 $\Delta^{877-880}$ receptor, in that they extend into all neurites, whereas the Lys ${ }^{880} \mathrm{Ala}$ mutant is similar to mGluR1b-myc, the receptor being excluded from distal dendritic processes labeled with MAP2 (red, open arrowheads; an arrow points to a double-labeled proximal dendrite). Scale bars, $20 \mu \mathrm{m}$. B, Localization of mutant mGluR1b receptors ( green) in MDCK cells double labeled for E-cadherin (red). The distribution of the $\operatorname{Arg}^{877}$-, $\mathrm{Arg}^{878}$, and Lys ${ }^{879}$-Ala mutants is nonpolar, and the Lys ${ }^{880}$-Ala mutant is targeted to the apical domain as mGluR1b-myc.

apically (Fig. 7Q). These findings indicate that the region of the mGluR1a tail between residues 1012 and 1071 acts as a dominant dendritic and basolateral signal, thus masking the $\mathrm{RRK}^{877-879}$ motif.

\section{The cytoplasmic tails of mGluR1 $a$ and $b$ are sufficient to direct targeting}

To assess whether the RRK ${ }^{877-879}$ motif and the targeting signal harbored by the tail of mGluR1a can function autonomously to direct targeting, we joined the tails of mGluR1a and mGluR1b in frame with a truncated form of VSV-G. VSV-G is a type I transmembrane protein that targets to the basolateral domain of
MDCK cells through a tyrosine-based signal located in its cytoplasmic tail. Truncated forms of the protein lacking the targeting signal have been reported to lose their polar distribution (Thomas et al., 1993). We generated a truncated VSV-G lacking the tail (VSVG ${ }^{\text {ts }}$-stop) and three chimeras in which the tail was replaced with that of mGluR1a (VSVG ${ }^{\text {ts }}-1$ atail), mGluR1b $\left(V_{S V G}{ }^{\text {ts }}\right.$ 1btail), and mGluR1b $\Delta^{877-880}$ (VSVG $^{\text {ts }}-1 \mathrm{~b} \Delta^{877-880}$ ). When expressed in MDCK cells at the permissive temperature, $\mathrm{VSVG}^{\text {ts }}$ stop was delivered to both the apical and basolateral compartments (Fig. 8A), consistent with previous studies. The VSVG ${ }^{\text {ts }}$ 1atail chimera was instead prevalently localized to the basolateral 


\begin{abstract}
A TM7
KPERNVRSAFTTSDVVRMHVGDGKLPCRSNTFLNIFRRKKPGAGNANSNGKSVSWSEPGGRQAPKGQHVWQRLSVHVKTNETACNQTAVIKPLT KSYOGSGKSLTFSDASTKTLYNVEEEDNTPSAHFSPPSSPSMVVHRRGPPVATTPPLPPHLTAEETPLFLADSVIPK GLPPPLPQQQPQQPPP QQPPQQPKSLMDQLQGVVTNFGSGIPDFHAVLAGPGTPGNSLRS LYPPPPPPQHLQMLPLHLSTFQEESISPPGEDIDDDSERF KLLQEFVY EREGNTEEDELEEEEDLPTASKLTPEDSP•ALTPPSPFRDSVASGSSVPSSPVSESVLCTPPNV TYASVILRDYKQSSSTL
\end{abstract}

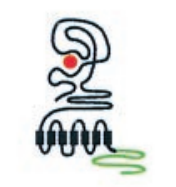

mGluR1a-1182stop
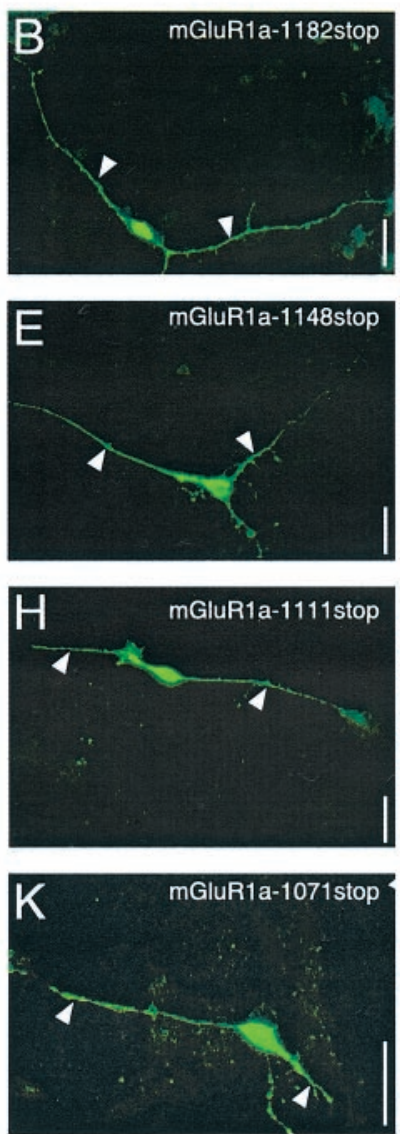

mGluR1a-1071stop

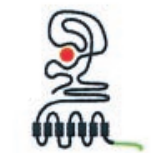

mGluR1a-1011stop
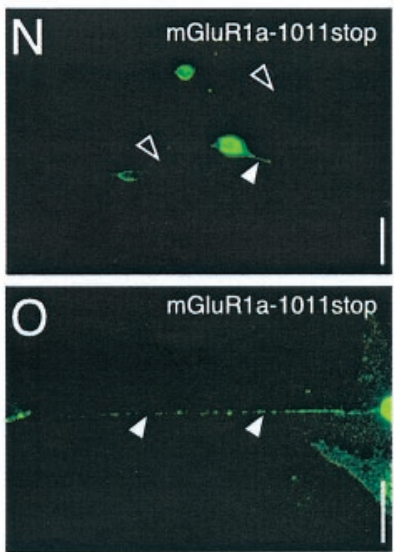
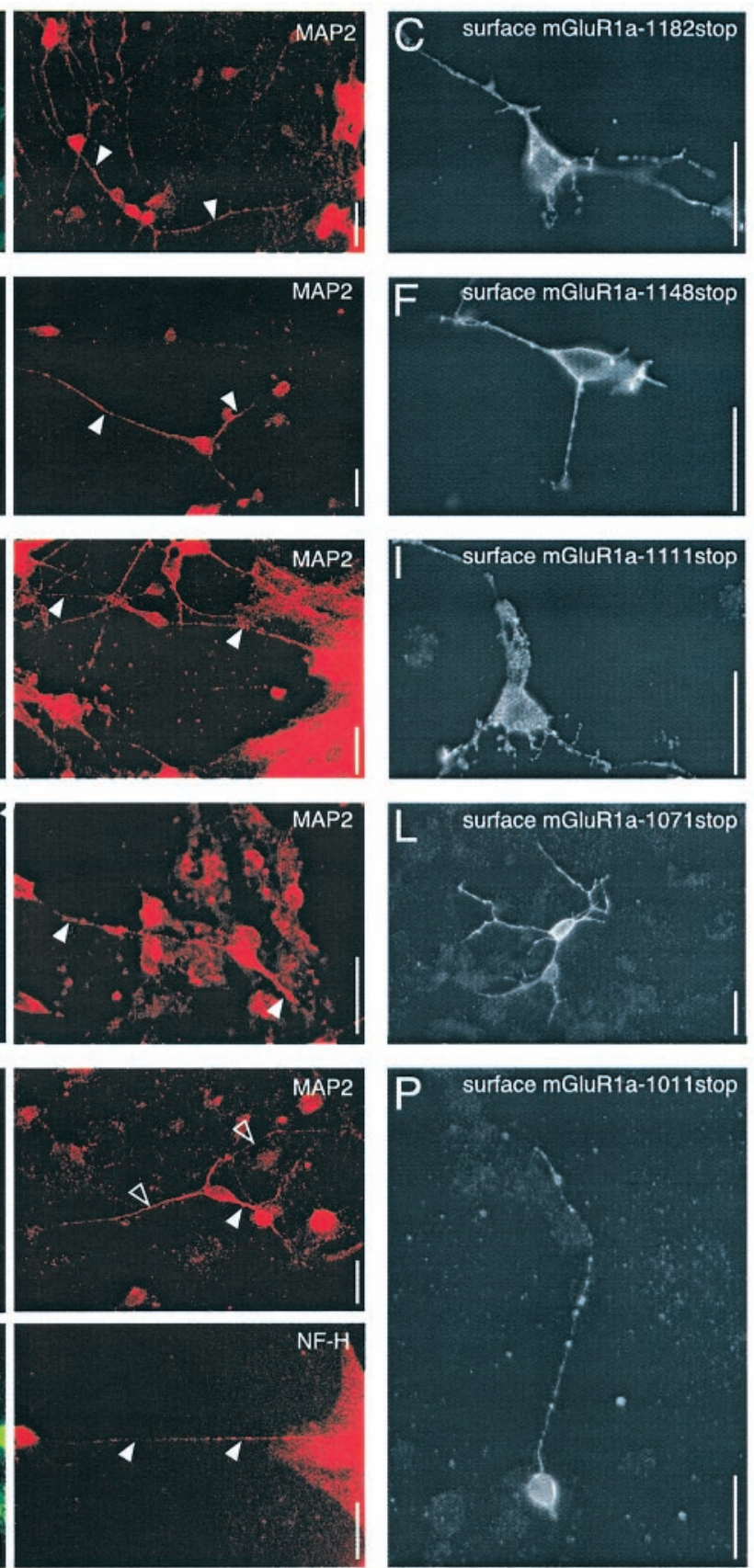

$D$

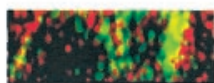

G

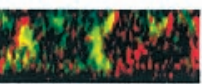

$\mathrm{J}$

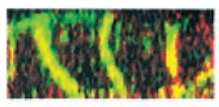

M
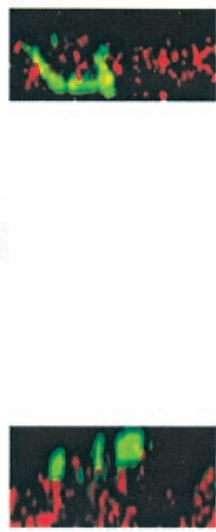

Figure 7. The RRK ${ }^{877-879}$ motif is masked in mGluR1a by dominant dendritic and basolateral signals in the receptor tail. $A$, Amino acid sequence of the intracellular tail of mGluR1a; green circles in the sequence indicate the positions of the stop codons introduced to generate serial deletions of the tail. Retina neurons were transfected with mGluR1a-myc deletion mutants ( green) and double-labeled in red with MAP2 (B, E, H, K, $N$; mGluR1a1182stop, $n=4$; mGluR1a-1148stop, $n=5$; mGluR1a-1111stop, $n=5$; mGluR1a-1071stop, $n=3$; and mGluR1a-1011stop, $n=6$; results are from 3 independent experiments) and NF-H $(O$; mGluR1a-1011stop, $n=6)$. In one cell from three experiments analyzed for each construct, both mGluR1a-1148stop and mGluR1a-1111stop were found in NF-H-positive processes. Solid arrowheads point to double-labeled processes; open arrowheads indicate MAP2-positive, myc-negative dendrites. The truncated mGluR1a mutants are present on the plasma membrane, as shown by in vivo labeling $(C, F, I)$ or immunofluorescence on fixed but nonpermeabilized neurons $(L, P)$. Scale bars, $20 \mu \mathrm{m} . D, G, J, M, Q, z$-sections through confocal images of polarized MDCK cells expressing mGluR1a deletion mutants. Myc-tagged receptors are in green, and the basolateral marker E-cadherin is in red. TM7, Transmembrane domain 7. 

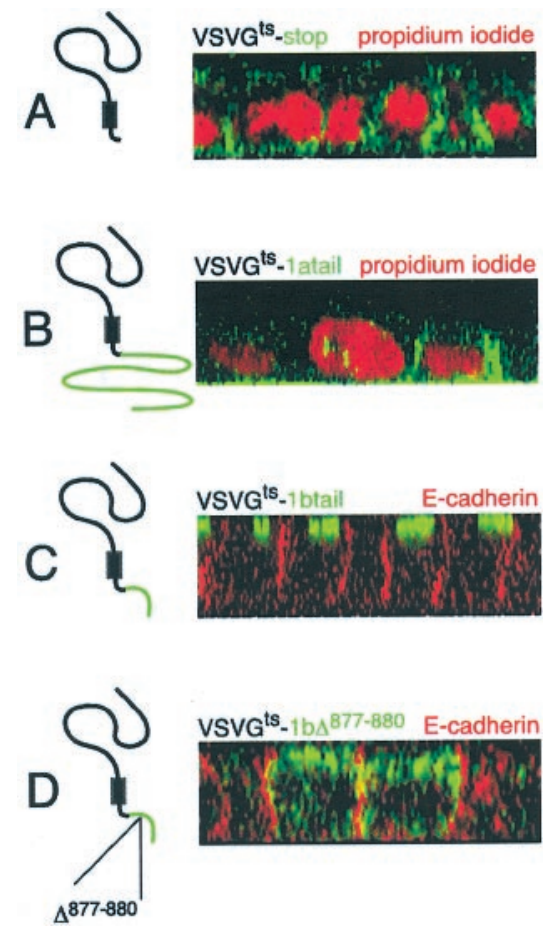

Figure 8. The RRK ${ }^{877-879}$ motif is necessary and sufficient for apical targeting. $A$, The truncated VSV-G protein $\mathrm{VSVG}^{\mathrm{ts}}$-stop (in green) is detected on both apical and basolateral domains with an antibody against the ectodomain of VSV-G. In red are the cell nuclei labeled with propidium iodide. $B$, The $\mathrm{VSVG}^{\mathrm{ts}}$-1atail chimera is targeted to the basolateral compartment. $C$, The $\mathrm{VSVG}^{\text {ts }}-1$ btail chimera is apically targeted, as shown by double labeling with antibodies against the mGluR1b tail (green) and E-cadherin (red). D, The VSVG ${ }^{\mathrm{ts}}-1 \mathrm{~b} \Delta^{877-880}$ chimera (green) lacking the RRK motif is not selectively targeted to the apical compartment; yellow puncta indicate colocalization with E-cadherin (red) on the basolateral surface.
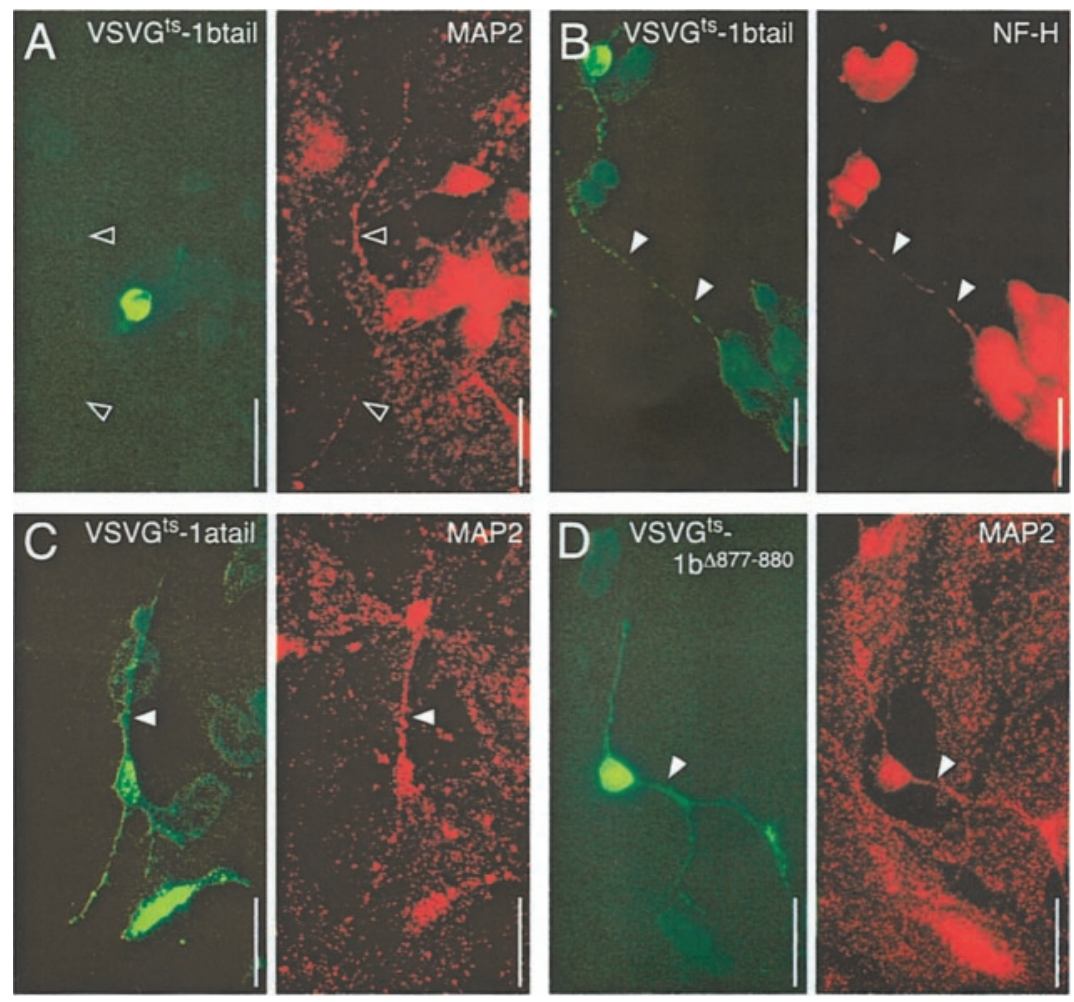

compartment, confirming the presence of a dominant basolateral targeting signal in the tail of the long splice variant of the receptor (Fig. $8 B$ ). Analysis of cells expressing VSVG ${ }^{\text {ts }}$ - 1 btail showed that the tail of mGluR1b was sufficient to redirect the chimera to the apical compartment (Fig. $8 C$ ). In contrast, VSVG ${ }^{\text {ts }}-1 \mathrm{~b} \Delta^{877-}$ 880 was not selectively targeted to the apical domain (Fig. $8 D$ ) and was mostly retained inside the cell. Consistent with their localization in MDCK cells, when expressed in retina neurons the $\mathrm{VSVG}^{\text {ts }}$-1btail chimera was excluded from distal dendrites (Fig. 9A;n=3) and present in axonal processes (Fig. 9B; $n=$ $4)$, whereas the VSVG ${ }^{\text {ts }}-1$ atail and VSVG ${ }^{\text {ts }}-1 \mathrm{~b} \Delta^{877-880}$ chimeras were found in MAP2-positive dendrites (Fig. 9C, $D ; n=4$ and 2 , respectively).

\section{DISCUSSION}

We have identified in the C-terminal tail of the seventransmembrane receptor mGluR1 a discrete cytoplasmic signal, which drives axonal targeting in neurons and apical targeting in epithelial cells. This signal, the $\mathrm{RRK}^{877-879}$ tripeptide, is both necessary and sufficient for targeting, because it can redirect a protein with nonpolar distribution selectively to axonal and apical compartments. The $\mathrm{RRK}^{877-879}$ tripeptide in the C-terminal tail of mGluR1 resembles the RXR motif, which regulates retention and retrieval to the endoplasmic reticulum of the $\mathrm{K}^{+} \mathrm{ATP}$ channel (Zerangue et al., 1999), the heterodimeric $\mathrm{GABA}_{\mathrm{B}}$ receptor (Margeta-Mitrovic et al., 2000), and the NR1 subunit of NMDA receptors (Standley et al., 2000). Both $\mathrm{RRK}^{877-879}$ and RXR are internal to the cytoplasmic tail of proteins and not close to the C-terminal end, as for other trafficking signals (Teasdale and Jackson, 1996); both function independently of the overall protein structure. In addition, the RRKK ${ }^{877-880}$ region has also been implicated recently in regulating the efficiency of receptor transport to the plasma membrane (Chan et al., 2001). Together, these observations point to the existence of a new group of structurally 
related motifs controlling the progress of complex plasma membrane proteins through different trafficking checkpoints.

Sphingolipid-cholesterol rafts are primarily believed to operate in the apical transport of proteins in epithelial cells (Simons and Ikonen, 1997), and their involvement in axonal transport has also been put forward. An indication of the association of a protein with rafts is generally given by its solubility in Triton X-100 and flotation properties. According to these criteria, the mGluR1b receptor does not appear to use a raft-dependent pathway for its localization to the axonal and apical domains, suggesting the existence of alternative routes of transport in which the RRK ${ }^{877-879}$ motif may be engaged. However, we cannot exclude the possibility that lack of association with lipid rafts could be attributable to a very tight link of the receptor with cytoskeleton proteins, which could also cause its high density in sedimentation. An alternative sorting mechanism, also proposed to operate in apical targeting, is the secretion of an intracellular compartment where apically destined proteins would be clustered, possibly by homotypic interactions (Yeaman et al., 1999). Such an intracellular compartment has been described, but the identity of its components and the mechanism of its formation are still unclear. It has been shown recently that the cytoplasmic tail of multispan membrane proteins could also function as an apical determinant (Chuang and Sung, 1998; Muth et al., 1998). These findings suggested that apical targeting may operate, as for basolateral targeting, via the interaction of discrete peptide motifs with specialized components of the sorting machinery. However, no discrete cytoplasmic motif acting as signal, as for basolateral targeting, had been identified.

The mechanisms and signals regulating axonal targeting are also still poorly understood (Winckler and Mellman, 1999b). The $\mathrm{RRK}^{877-879}$ tripeptide is the first discrete motif required for axonal targeting identified thus far. Previous reports have shown that cytoplasmic regions of a neurotransmitter receptor and a synaptic vesicle-associated protein (West et al., 1997b; Stowell and Craig, 1999) are necessary for their entry in the axon. It is intriguing that sequences similar to the $\mathrm{RRK}^{877-879}$ motif are also present within these regions, where they may have an equivalent function. Additional evidence for cytosolic sorting signals operating in neuronal trafficking was given by the recent identification of a clustering motif that restricts the localization of the $\mathrm{Kv} 2.1 \mathrm{~K}^{+}$ channel to the soma and proximal dendrites. This signal is also present in the intracellular C-terminal tail of the channel (Lim et al., 2000).

Neurons may use several distinct mechanisms to achieve subcellular compartmentalization of synaptic components. For example, selective interaction with anchoring molecules, such as PSD-95/Dlg/ZO-1 domain proteins, mediates clustering of ionotropic glutamate receptors at postsynaptic sites (Hayashi et al., 2000; Rongo et al., 1998). Furthermore, a cytoskeleton-based fence at the initial segment of the axon has been proposed to exert a role in controlling diffusion of membrane proteins between compartments (Winckler and Mellman, 1999a). The RRK $^{877-879}$ tripeptide could be recognized during sorting, required for retention at specific sites, or involved in interactions with the cytoskeleton; the identification of interacting proteins should help answer these questions.

The $\mathrm{RRK}^{877-879}$ signal is present in a region of the C-terminal tail that is conserved among different mGluR 1 splice variants. However, this motif is not functional in mGluR1a, which is targeted to the dendritic and basolateral compartment. Serial deletions of the mGluR1a tail 313 residues revealed the existence of at least two groups of targeting signals involved in trafficking of this receptor. First, a crucial structural signal regulating mGluR1a trafficking is comprised between residues 1012-1071; deletion of this region of the tail prevents both dendritic and basolateral targeting of the receptor. Its removal appears to unmask the RRK ${ }^{877-879}$ motif, thus making it available for interaction with the trafficking machinery. These findings are well in agreement with the observation that proteins often harbor both apical and basolateral signals, with the latter usually dominant (Matter and Mellman, 1994; Rodriguez-Boulan and Gonzalez, 1999), and that deletion of the basolateral signal frequently confers apical targeting. Second, deletion of a region comprised between residues 1148-1182 appears to reduce the fidelity of dendritic and basolateral targeting, as indicated by the presence of the receptor in the apical compartment and occasional axonal labeling in a small percentage of neurons. This region of the mGluR1a tail harbors both a critical leucine residue within a motif (EDSPA $L^{1145-1150}$ ) closely related to a novel, recently identified, basolateral targeting signal (Wehrle-Haller and Imhof, 2001) and the binding site for homer proteins PPSPFR ${ }^{1152-1157}$ (Brakeman et al., 1997; Tu et al., 1998). Homer proteins have been shown recently to be involved in trafficking of mGluR5 from the endoplasmic reticulum in heterologous cells (Roche et al., 1999) and to the dendritic and axonal compartments in neurons (Ango et al., 2000). Interestingly, homer proteins are present in a wide variety of tissues (Xiao et al., 1998), including kidney, pointing to a more general trafficking function for these proteins in cells other than neurons. Together, these observations suggest that trafficking of the two mGluR1 splice variants may occur via different secretory pathways and that their segregation may take place early, at the exit from the endoplasmic reticulum (Bannykh et al., 1998; Muniz et al., 2001).

Overall, the distribution of the mGluR1 a and b splice variants in transfected primary neurons mirrors their cellular localization in the CNS. Indeed, mGluR1a is predominantly somatodendritic in many brain regions, among them retina (Koulen et al., 1997), cerebellum, and hippocampus (Martin et al., 1992; Baude et al., 1993), whereas mGluR1b localizes to the somata and proximal dendritic segments in Purkinje cells (Mateos et al., 2000) and possibly in axons in the hippocampus and striatum (Ferraguti et al., 1998; Mateos et al., 1998). The segregation of the two receptors to distinct cellular compartments strongly suggests that they may subserve different signaling functions even within the same neuron. This previously unappreciated level of complexity raises the question of what is the relative contribution of each mGluR1 splice variant to the regulation of higher functions, such as learning and memory, to which the receptor has been linked (Aiba et al., 1994a,b; Conquet et al., 1994).

\section{REFERENCES}

Aiba A, Chen C, Herrup K, Rosenmund C, Stevens CF, Tonegawa S (1994a) Reduced hippocampal long-term potentiation and contextspecific deficit in associative learning in mGluR1 mutant mice. Cell 79:365-375.

Aiba A, Kano M, Chen C, Stanton ME, Fox GD, Herrup K, Zwingman TA, Tonegawa S (1994b) Deficient cerebellar long-term depression and impaired motor learning in mGluR1 mutant mice. Cell 79:377-388. Allgood VE, Zhang YZ, O’Malley BW, Weigel NL (1997) Analysis of chicken progesterone receptor function and phosphorylation using an adenovirus-mediated procedure for high efficiency DNA transfer. Biochemistry 36:224-232.

Ango F, Pin J-P, Tu JC, Xiao B, Worley PF, Bockaert J, Fagni L (2000) Dendritic and axonal targeting of type 5 metabotropic glutamate receptor is regulated by Homer1 proteins and neuronal excitation. J Neurosci 20:8710-9716. 
Bannykh SI, Nishimura N, Balch WE (1998) Getting into the Golgi. Trends Cell Biol 8:21-25.

Baude A, Nusser Z, Roberts JD, Mulvihill E, McIlhinney RA, Somogyi $\mathrm{P}$ (1993) The metabotropic glutamate receptor (mGluR1 $\alpha$ ) is concentrated at perisynaptic membrane of neuronal subpopulations as detected by immunogold reaction. Neuron 11:771-787.

Brakeman PR, Lanahan AA, O’Brien R, Roche K, Barnes CA, Huganir RL, Worley PF (1997) Homer: a protein that selectively binds metabotropic glutamate receptors. Nature 386:284-288.

Chan WY, Soloviev MM, Ciruela F, McIlhinney RAJ (2001) Molecular determinants of metabotropic glutamate receptor 1B trafficking. Mol Cell Neurosci 17:577-588.

Chuang J-Z, Sung C-H (1998) The cytoplasmic tail of rhodopsin acts as a novel apical sorting signal in polarized MDCK cells. J Cell Biol 142:1245-1256.

Conn PJ, Pin J-P (1997) Pharmacology and functions of metabotropic glutamate receptors. Annu Rev Pharmacol Toxicol 37:205-237.

Conquet F, Bashir ZL, Davies CH, Daniel H, Ferraguti F, Bordi F, Franz-Bacon F, Reggiani A, Matarese V, Conde F, Collingridge GL, Crepel F (1994) Motor deficit and impairment of synaptic plasticity in mice lacking mGluR1. Nature 372:237-243.

Ferraguti F, Conquet F, Corti C, Grandes P, Kuhn R, Knopfel T (1998) Immunohistochemical localization of the mGluR1b metabotropic glutamate receptor in the adult rodent forebrain: evidence for a differential distribution of mGluR1 splice variants. J Comp Neurol 400:391-407

Flor PJ, Gomeza J, Tones MA, Kuhn R, Pin JP, Knopfel T (1996) The C-terminal domain of the mGluR1 metabotropic glutamate receptor affects sensitivity to agonists. J Neurochem 67:58-63.

Francesconi A, Duvoisin RM (1998) Role of the second and third intracellular loops of metabotropic glutamate receptors in mediating dual signal transduction activation. J Biol Chem 273:5615-5624.

Gossen M, Bujard H (1992) Tight control of gene expression in mammalian cells by tetracycline-responsive promoters. Proc Natl Acad Sci USA 89:5547-5551.

Harder T, Scheiffele P, Verkade P, Simons K (1998) Lipid domain structure of the plasma membrane revealed by patching of membrane components. J Cell Biol 141:929-942.

Hayashi Y, Shi S-H, Esteban JA, Piccini A, Poncer J-C, Malinow R (2000) Driving AMPA receptors into synapses by LTP and CAMKII: requirement for GluR1 and PDZ domain interaction. Science 287:2262-2267.

Herrero I, Miras-Portugal T, Sanchez-Prieto J (1992) Positive feedback of glutamate exocytosis by metabotropic presynaptic receptor stimulation. Nature 360:163-166.

Houamed KM, Kuijper JL, Gilbert TL, Haldeman BA, O'Hara PJ, Mulvihill ER, Almers W, Hagen FS (1991) Cloning, expression, and gene structure of a $\mathrm{G}$ protein-coupled glutamate receptor from rat brain. Science 252:1318-1321.

Jacobson K, Dietrich C (1999) Looking at lipid rafts? Trends Cell Biol 9:87-91.

Jareb M, Banker G (1998) The polarized sorting of membrane proteins expressed in cultured hippocampal neurons using viral vectors. Neuron 20:855-867.

Koulen P, Kuhn R, Wässle H, Brandstätter JH (1997) Group I metabotropic glutamate receptors mGluR1 $\alpha$ and mGluR5a: localization in both synaptic layers of the rat retina. J Neurosci 17:2200-2211.

Ledesma MD, Simons K, Dotti CG (1998) Neuronal polarity: essential role of protein-lipid complexes in axonal sorting. Proc Natl Acad Sci USA 95:3966-3971.

Lim ST, Antonucci DE, Scannevin RH, Trimmer JS (2000) A novel targeting signal for proximal clustering of the $\mathrm{Kv} 2.1 \mathrm{~K}^{+}$channel in hippocampal neurons. Neuron 25:385-397.

Margeta-Mitrovic M, Jan YN, Jan LY (2000) A trafficking checkpoint controls $\mathrm{GABA}_{\mathrm{B}}$ receptor heterodimerization. Neuron 27:97-106.

Martin LJ, Blackstone CD, Huganir RL, Price DL (1992) Cellular localization of a metabotropic glutamate receptor in rat brain. Neuron 9:259-270.

Mary S, Gomeza J, Prézeau L, Bockaert J, Pin J-P (1998) A cluster of basic residues in the carboxyl-terminal tail of the short metabotropic glutamate receptor 1 variants impairs their coupling to phospholipase C. J Biol Chem 273:425-432.

Masu M, Tanabe Y, Tsuchida K, Shigemoto R, Nakanishi S (1991) Sequence and expression of a metabotropic glutamate receptor. Nature 349:760-765.

Mateos JM, Azkue J, Benitez R, Sarria R, Losada J, Conquet F, Ferraguti F, Kuhn R, Knopfel T, Grandes P (1998) Immunocytochemical localization of the mGluR1b metabotropic glutamate receptor in the rat hippocampus. J Comp Neurol 390:225-233.
Mateos JM, Benitez R, Elezgarai I, Azkue JJ, Lazaro E, Osorio A, Bilbao A, Donate F, Sarria R, Conquet F, Ferraguti F, Kuhn R, Knopfel T, Grandes P (2000) Immunolocalization of the mGluR1b splice variant of the metabotropic glutamate receptor 1 at parallel fiber-Purkinje cell synapses in the rat cerebellar cortex. J Neurochem 74:1301-1309.

Matter K, Mellman I (1994) Mechanisms of cell polarity: sorting and transport in epithelial cells. Curr Opin Cell Biol 6:545-554.

Muniz M, Morsomme P, Riezman H (2001) Protein sorting upon exit from the endoplasmic reticulum. Cell 104:313-320.

Muth TR, Ahn J, Caplan MJ (1998) Identification of sorting determinants in the C-terminal cytoplasmic tails of the $\gamma$-aminobutyric acid transporter GAT-2 and GAT-3. J Biol Chem 273:25616-25627.

Pin J-P, Duvoisin RM (1995) The metabotropic glutamate receptors: structure and function. Neuropharmacology 34:1-26.

Roche KW, Tu JC, Petralia RS, Xiao B, Wenthold RJ, Worley PF (1999) Homer $1 \mathrm{~b}$ regulates the trafficking of group I metabotropic glutamate receptors. J Biol Chem 274:25953-25957.

Rodriguez-Boulan E, Gonzalez A (1999) Glycans in post-Golgi apical targeting: sorting signals or structural props? Trends Cell Biol 9:291-294.

Rodriguez-Boulan E, Powell SK (1992) Polarity of epithelial and neuronal cells. Annu Rev Cell Biol 8:395-427.

Rodriguez-Moreno A, Sistiaga A, Lerma J, Sanchez-Prieto J (1998) Switch from facilitation to inhibition of excitatory synaptic transmission by group I mGluR desensitization. Neuron 21:1477-1486.

Rongo C, Whitfield CW, Rodal A, Kim SK, Kaplan JM (1998) LIN-10 is a shared component of the polarized protein localization pathways in neurons and epithelia. Cell 94:751-759.

Shaw G, Osborn M, Weber K (1986) Reactivity of a panel of neurofilament antibodies on phosphorylated and dephosphorylated neurofilaments. Eur J Cell Biol 42:1-9.

Simons K, Ikonen E (1997) Functional rafts in cell membranes. Nature 387:569-572.

Standley S, Roche KW, McCallum J, Sans N, Wenthold RJ (2000) PDZ domain suppression of an ER retention signal in NMDA receptor NR1 splice variants. Neuron 28:887-898.

Stowell JN, Craig AM (1999) Axon/dendrite targeting of metabotropic glutamate receptors by their cytoplasmic carboxy-terminal domains. Neuron 22:525-536.

Tanabe Y, Masu M, Ishii T, Shigemoto R, Nakanishi S (1992) A family of metabotropic glutamate receptors. Neuron 8:169-179.

Teasdale RD, Jackson MR (1996) Signal-mediated sorting of membrane proteins between the endoplasmic reticulum and the golgi apparatus. Annu Rev Cell Dev Biol 12:27-54.

Thomas DNC, Brewer CB, Roth MG (1993) Vesicular stomatitis virus glycoprotein contains a dominant cytoplasmic basolateral sorting signal critically dependent upon a tyrosine. J Biol Chem 268:3313-3320.

Tu JC, Xiao B, Yuan JP, Lanahan AA, Leoffert K, Li M, Linden DJ, Worley PF (1998) Homer binds a novel proline-rich motif and links group 1 metabotropic glutamate receptors with IP3 receptors. Neuron 21:717-726.

Wehrle-Haller B, Imhof BA (2001) Stem cell factor presentation to c-kit. J Biol Chem 276:12667-12674.

Weimbs T, Low S-H, Chapin SJ, Mostov KE (1997) Apical targeting in polarized epithelial cells: there's more afloat than rafts. Trends Cell Biol 7:393-399.

West AE, Neve RL, Buckley KM (1997a) Identification of a somatodendritic targeting signal in the cytoplasmic domain of the transferrin receptor. J Neurosci 17:6038-6047.

West AE, Neve RL, Buckley KM (1997b) Targeting of the synaptic vesicle protein synaptobrevin in the axon of cultured hippocampal neurons: evidence for two distinct sorting steps. J Cell Biol 139:917-927.

Winckler B, Mellman I (1999a) A diffusion barrier maintains distribution of membrane proteins in polarized neurons. Nature 397:698-701.

Winckler B, Mellman I (1999b) Neuronal polarity: controlling the sorting and diffusion of membrane components. Neuron 23:637-640.

Xiao B, Tu JC, Petralia RS, Yuan JP, Doan A, Breder CD, Ruggiero A, Lanahan AA, Wenthold RJ, Worley PF (1998) Homer regulates the association of group 1 metabotropic glutamate receptors with multivalent complexes of homer-related, synaptic proteins. Neuron 21:707-716.

Yeaman C, Grindstaff KK, Nelson JW (1999) New perspectives on mechanisms involved in generating epithelial cell polarity. Physiol Rev 79:73-98.

Zerangue N, Schwappach B, Jan YN, Jan LY (1999) A new ER trafficking signal regulates the subunit stoichiometry of plasma membrane $\mathrm{K}_{\text {ATP }}$ channels. Neuron 22:537-548. 